\title{
Cerebellar Granulocytic Sarcoma: A Case Report
}

\author{
Serebellar Granülositik Sarkom: Bir Olgu Sunumu
}

\author{
Birol Baytan ${ }^{1}$, Melike Sezgin Evim ${ }^{1}$, Adalet Meral Güneş ${ }^{1}$, Hasan Kocaeli², Şaduman Balaban³ \\ Ender Korfalı², Nükhet Tüzüner ${ }^{4}$ \\ ${ }^{1}$ Uludağ University, School of Medicine, Department of Pediatric Hematology, Bursa, Turkey \\ ${ }^{2}$ Uludağ University, School of Medicine, Department of Neurosurgery, Bursa, Turkey \\ ${ }^{3}$ Uludağ University, School of Medicine, Department of Pathology, Bursa, Turkey \\ ${ }^{4}$ İstanbul University, School of Medicine, Department of Pathology, Bursa, Turkey
}

\begin{abstract}
Granulocytic sarcoma is a rare tumor composed of immature granulocytic cells that is usually associated with acute myelogenous leukemia. Intraparenchymal cranial localization without skull, meningeal, or bone marrow invasion is extremely rare. The mechanisms of intraparenchymal cranial localization of GS remains unknown, as only 10 cases with cerebellar granulocytic sarcoma have been previously reported. Herein, we report a four year old boy with cerebellar localization of granulocytic sarcoma.
\end{abstract}

Key Words: Children, Acute leukemia, Granulocytic sarcoma

Özet

Granulositik sarkom, genellikle akut myelositer lösemiye eşlik eden immatür granülositik hücrelerden oluşan nadir bir tümördür. Kafatası, meninks ve kemik iliği tutulumu olmaksızın izole intrakranial parankimal tutulum ise çok daha nadirdir ve mekanizması henüz tam olarak bilinmemektedir. Literatürde 10 vaka bildirilmiştir. Bu raporumuzda kemik iliği tutulumu olmadan izole serebellar parankimde yer alan granülositik sarkom tartışılmıştır.

Anahtar Sözcükler: Çocuk, Akut lösemi, Granülositik sarkom

\section{Introduction}

Granulocytic sarcoma (GS) is a rare extramedullary solid tumor. GS, which is synonymous with chloroma, myeloblastoma, and extramedullary leukemia, is a localized tumor composed of leukemic myeloblasts and myeloid precursors. The clinical characterization of GS is classified into 4 groups: a) primary GS; b) GS at onset of acute myelogenous leukemia (AML); c) GS as an isolated recurrence of AML (new isolated focus of GS that occurs during bone marrow remission); d) GS with concurrent bone marrow relapse of AML [1-4]. The precise incidence rate of GS is not known, although it occurs in approximately $3 \%$ of patients with leukemia $[4,5]$. The most common sites of involvement are bone, periosteum, soft tissue, lymph nodes, and skin; however, intraparenchymal involvement of GS in the central nervous system (CNS) is rare [6-8]. Some Turkish researchers have reported that there is an association between AML and GS [9-12]. Çavdar et al. being the first in 1971 [13]. Herein we present a patient with the unusual presentation of cerebellar parenchymal GS invasion without skull, meningeal, or bone marrow invasion after completing treatment for AML.

Address for Correspondence: Birol BAYTAN, M.D.,

Uludağ Üniversitesi, Tıp Fakültesi, Çocuk Sağlığı ve Hastalıkları Anabilim Dalı, 16059, Bursa, Turkey

Phone: +90 22444284 00/1107 E-mail: baytanbirol@yahoo.com

Received/Geliş tarihi : June 24, 2009

Accepted/Kabul tarihi : April 30, 2010 


\section{Case Report}

A 4-year-old boy was diagnosed as AML without CNS involvement in May 2008. Bone marrow aspirate showed diffuse infiltration of monoblasts (90\%). Flow cytometric analysis showed that these blasts were positive for myeloperoxidase, CD15, CD33, CD13, CD14, and CD4. Based on all these findings, the diagnosis of AML, FAB subtype M5 was confirmed. Complete remission was achieved following 4 courses of the Medical Research Council (MRC) UK-AML 12 chemotherapy protocol (2. remission induction courses with cytarabine, daunorubicin, and etoposide [ADE] given for 10, 3, and $5 \mathrm{~d}$, respectively, for the $1^{\text {st }}$ course, and 8,3 , and $5 \mathrm{~d}$, respectively, for the $2^{\text {nd }}$ course, and 2 consolidation courses consisting of amsacrine, cytarabine, etoposide [MACE], and MidAC [mitoxantrone, cytarabine] and triple intrathecal chemotherapy given once after each chemotherapy courses [14]. Informed consent was obtained from patient's family.

At the end of the re-consolidation phase of treatment the patient had frontal headache, but no fever or neurological findings. Cranial magnetic resonance imaging (MRI) performed due to the persistent headache showed a $4 \times 4.5$ $\mathrm{x} 5-\mathrm{cm}$ mass lesion in the right cerebellar hemisphere. The lesion was hypointense on Tl-weighted and hyperintense on T2-weighted MRI, and showed linear heterogeneous enhancement after administration of Gd-DTPA (Figure 1). Left facial weakness and a slight increase in deep tendon reflexes were noted within 2 hours after cranial MRI. Neurological examination showed that the patient had aphasia, hemiparesis, papilloedema, and $3^{\text {rd }}$ (III), $7^{\text {th }}$ (VII), and $9^{\text {th }}$ (IX) cranial nerve palsies, and he was scheduled for surgery.

During preparation for surgery the patient's clinical condition continued to deteriorate and he became comatose, with dilated non-reactive pupils and extensor posturing in response to painful stimuli. Because these findings suggested tonsillar herniation, the patient underwent emergency surgery and the mass was resected via right suboccipital craniotomy while in the sitting position. The mass was removed, with the exception of a small piece with a diameter of $1 \mathrm{~cm}$ that adhered to the brainstem and lower cranial nerves. Postoperatively the patient recovered in 2 days and regained consciousness and full physical strength. However the symptoms related to the $3^{\text {rd }}, 7^{\text {th }}$ and $9^{\text {th }}$ cranial nerves improved nvolved retarded. Cerebrospinal fluid (CSF) obtained during the surgery was acellular. Both CSF protein $\left(15 \mathrm{mg} \mathrm{dL}^{-1}\right)$ and lactate dehydrogenase (14 IU L ${ }^{-1}$ ) levels were within the normal range. Histopathologic examination showed that the mass was composed of undifferentiated mononuclear cells with monoblastic features (Figure 2). Immunohistochemical staining exhibited weak myeloperoxidase positivity, and strong CD34 and CD117 monoclonal antibody positivity. The patient's bone marrow aspiration done concurrently performed withwith cranial surgery was found in complete remission.

Two weeks after surgery, the patient received 10 doses of cranial radiotherapy (RT) with a each dose of 1200 cGy with a each dose. The the symptoms related to involved cranial nerve paralysis had improved following the cranial RT. were. As the patient's family refused systemic chemotherapy supportive therapy was initiated. Four week later the $10^{\text {th }}$ dose of RT, the patient developed widespread polypus masses on the gingiva, and renal ultrasonography performed due to abdominal pain showed hypoechoic lesions in the renal parenchyma. These findings were indicative of the dissemination of leukemia. His bone marrow aspiration done in the same time with the dissemination of leukemia
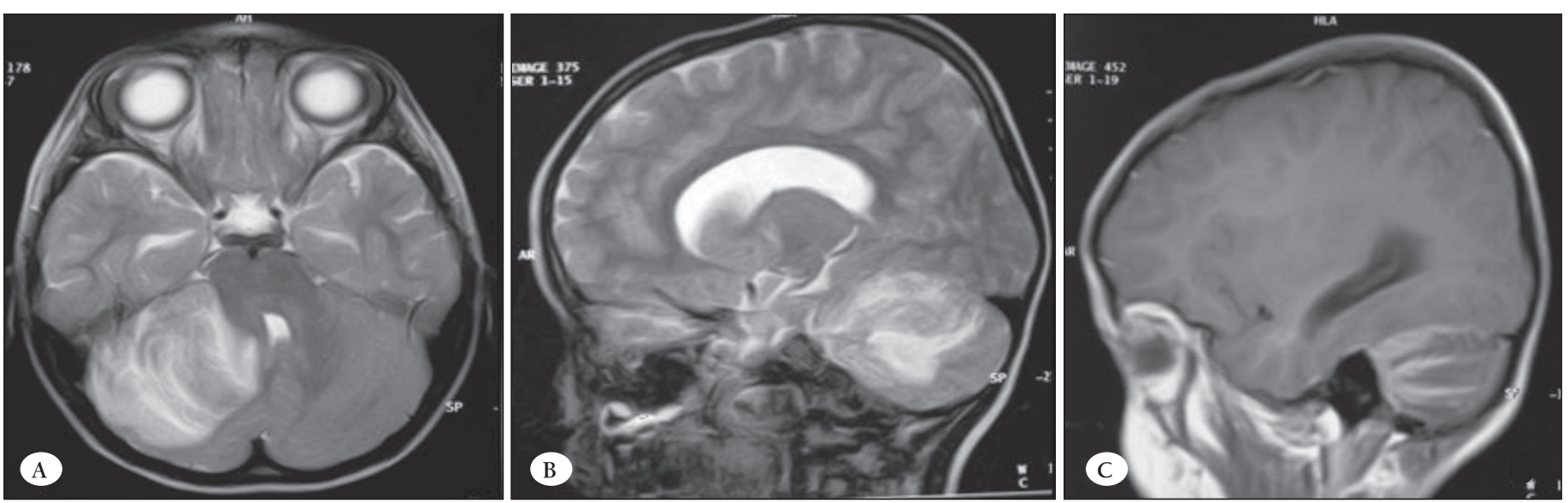

Figure 1: Axial (A) and sagittal (B-C) T1- and T2-weighted MRI with Gd-DTPA show the linear heterogeneously enhanced mass in the right cerebellar hemisphere. 


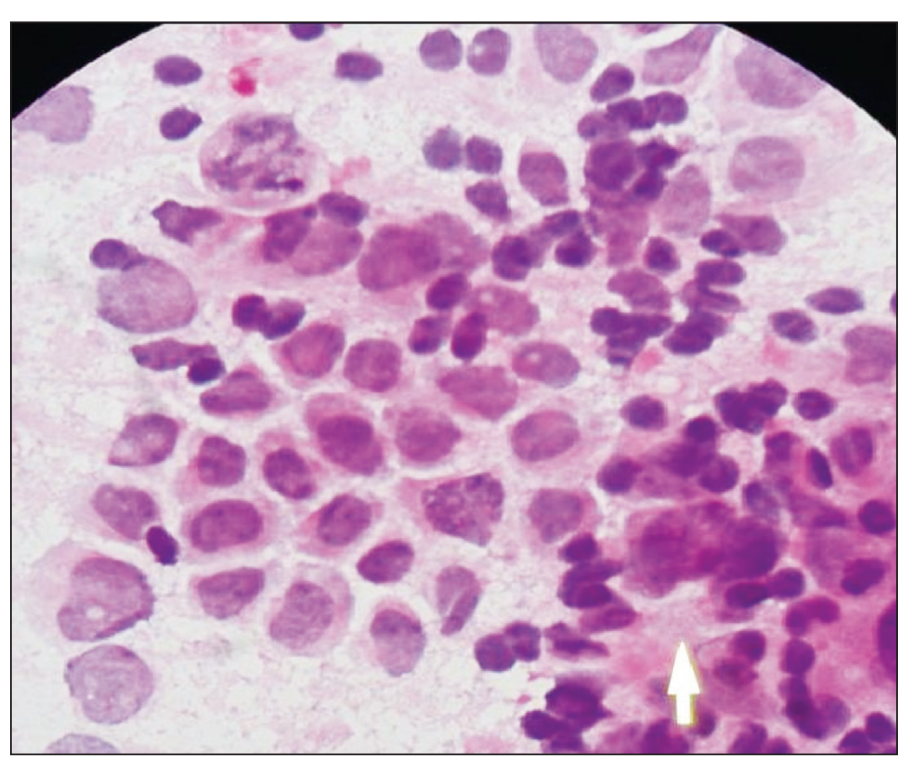

Figure 2: Photomicrograph shows diffuse undifferentiated mononuclear cells (hematoxylin and eosin, 100x).

was also found infiltrated. The patient's clinical condition progressively declined and he died 2 months after being diagnosed as cerebellar GS.

\section{Discussion}

The presented case developed cerebellar GS without CSF or bone marrow involvement. Intracranial GS without meningeal or skull invasion is extremely rare; only 10 pathologically proven cases have been reported [15]. There are 3 primary explanations of the pathogenesis of GS. The first is that the leukemic nodules arise from leukostatic plugging of small cerebral vessels during the acceleration of blastic phase [16]. The second is that leukemic cells passing through the first dura, and then the subarachnoid and Virchow-Robin spaces invade the brain surface [17]. The third is that the remainders of embryonic CNS cells capable of hematopoetic differentiation could undergo malignant transformation [18].

This presented case was morphologically classified as AML M5, based on flow cytometric observation of positive myeloid markers. The level of CD4 expression was high (98\%). FAB subtype M4 and M5 morphology, and the presence of myeloblasts with high-level expression of CD4 were reported to be factors that predispose to the development of GS [15]. CSF samples obtained from the patient at the time of diagnosis and during chemotherapy were acellular, with normal protein and LDH levels. Furthermore, CSF obtained from the ventricles at the time GS was diagnosed was also acellular. Although only a small number of cases have been reported, approximately 35\% of patients with intracranial GS had no CSF involvement $[19,20]$.

Management of GS in the presented patient included surgical mass excision and RT. Data on GS are scarce and its optimal treatment is unclear; therefore, it should be considered a leukemic relapse site and treated as a relapse with intensive chemotherapy and RT, even though the bone marrow does not show any leukemic infiltration. The presented patient received 10 doses of cranial RT, but as his family refused systemic chemotherapy he was given only supportive therapy. Despite the fact that GS is very radiosensitive, time to remission is reported and most patients die within 3 months [21-23]. In the presented case, 1 month after the completion of RT, leukemia was disseminated simultaneously infiltrating the gingiva, renal parenchyma, and bone marrow, and the patient died due to disseminated disease after 2 months of the diagnosis of the cerebellar GS.

\section{Conclusion}

GS in brain parenchyma without skull or meningeal involvement is very rare. Its mechanism of formation is still unknown. Some degree of improvement can be achieved in such patients with surgery and RT; however, the prognosis remains poor.

\section{Conflict of Interest Statement}

The authors of this paper have no conflicts of interest, including specific financial interests, relationships, and/ or affiliations relevant to the subject matter or materials included.

\section{References}

1. Byrd JC, Edenfield WJ, Shields DJ, Dawson NA: Extramedullary myeloid cell tumors in acute nonlymphocytic leukemia: A clinical review. J Clin Oncol 1995; 13: 18001816

2. Byrd JC, Edenfield WJ, Dow NS, Aylesworth C, Dawson $\mathrm{N}$ : Extramedullary myeloid cell tumors in myelodysplasticsyndromes: Not a true indication of impending acute myeloid leukemia. Leuk Lymphoma 1996; 21: 153-159

3. Mahendra P, Ager S, Bedlow AJ, Bloxham DM, Green AR, Marcus RE: Two unusual neurological presentations of granulocytic sarcoma in Philadelphia positive chronic myeloid leukaemia. Leuk Lymphoma 1994; 15: 351-355 
4. Byrd JC, Weiss RB, Arthur DC, Lawrence D, Baer MR, Davey F, Trikha ES, Carroll AJ, Tantravahi R, Qumsiyeh M, Patil SR, Moore JO, Mayer RJ, Schiffer CA, Bloomfield CD: Extramedullary leukemia adversely affects hematologic complete remission rate and overall survival in patients with $\mathrm{t}(8 ; 21)$ (q22;q22): Results from Cancer and Leukemia Group B 8461. J Clin Oncol 1997; 15: 466-475

5. Neiman RS, Barcos M, Berard C, Bonner H, Mann R, Rydell RE, Bennett JM: Granulocytic sarcoma: A clinic pathologic study of 61 biopsies cases. Cancer 1981; 48: 1426-1437

6. Barnett MJ, Busman WV: Granulocytic sarcoma of the brain: A case report and review of the literature. Radiology 1986; 160: 223-225

7. O’Brien J, Buckley O, Murphy C, Torreggiani WC: An unusual cause of persistent headache: Chloroma (2008: 2b). Eur Radiol 2008; 18: 1071-1072

8. Aki H, Baslar Z, Uygun N, Ozguroglu M, Tuzuner N: Primary granulocytic sarcoma of the urinary bladder: Case report and review of the literature. Urology 2002; 60: 345

9. Cavdar AO, Arcasoy A, Babacan E, Gözdaşoğlu S, Topuz U, Fraumeni JF Jr: Ocular granulocytic sarcoma (chloroma) with acute myelomonocytic leukemia in Turkish children. Cancer 1978; 41(4): 1606-1609

10. Cavdar AO, Babacan E, Gözdaşoğlu S, Kilicturgay K, Arcasoy A, Cin S, Ertem U, Erten J: High risk subgroup of acute myelomonocytic leukemia (AMML) with orbito-ocular granulocytic sarcoma (OOGS) in Turkish children. Retrospective analysis of clinical, hematological, ultrastructural and therapeutical findings of thirty-three OOGS. Acta Haematol 1989; 81: 80-85

11. Cavdar AO, Babacan E, Gözdasoglu S, Yavuz G, Unal E, Pamir A: T-lymphocyte sub-populations in orbito-ocular granulocytic sarcoma (OOGS) and acute myelocytic leukemia (AML): A preliminary study. Med Oncol Tumor Pharmacother 1993; 10: 113-115

12. Hiçsönmez G, Cetin M, Tuncer AM, Yenicesu I, Aslan D, Ozyürek E, Unal S: Children with acute myeloblastic leukemia presenting with extramedullary infiltration: The effects of high-dose steroid treatment. Leuk Res 2004; 28 : 25-34

13. Cavdar AO, Gözdasoğlu S, Arcasoy A, Demirağ B: Chloramalike ocular manifestations in Turkish children with acute myelomonocytic leukaemia. Lancet 1971; 1: 680-682
14. Gale RE, Hills R, Kottaridis PD, Srirangan S, Wheatley K, Burnett AK, Linch DC: No evidence that FLT3 status should be considered as an indicator for transplantation in acute myeloid leukemia (AML): An analysis of 1135 patients, excluding acute promyelocytic leukemia, from the UK MRC AML10 and 12 trials. Blood 2005; 106: 3658-3665

15. Suzer T, Colakoglu N, Cirak B, Keskin A, Coskun E, Tahta $\mathrm{K}$ : Intracerebellar granulocytic sarcoma complicating acute myelogenous leukemia: A case report and review of the literature. J Clin Neurosci 2004; 11: 914-917

16. Saper CB, Jarowski CI: Leukemic infiltration of the cerebellum in acute myelomonocytic leukemia. Neurology 1982; 32: 77-80

17. Azzarelli B, Roessmann U: Pathogenesis of central nervous system infiltration in acute leukemia. Arch Pathol Lab Med 1977;101: 203-205

18. Ho DM, Wong TT, Guo WY, Chang KP, Yen SH: Primary cerebellar extramedullary myeloid cell tumor mimicking oligodendroglioma. Acta Neuropathol 1997; 94: 398-402

19. Psiachou-Leonard E, Paterakis G, Stefanaki K, MikrakiChristou V, Haidas S: Cerebellar granulocytic sarcoma in an infant with CD56+ acute monoblastic leukemia. Leuk Res 2001; 25: 1019-1021

20. Struhal W, Oberndorfer S, Lahrmann H, Lindeck-Pozza E, Hess B, Nussgruber V, Pöhnl R, Dobner T, Grisold W: Myeloid sarcoma in the central nervous system: Case report and review of the literature. Acta Clin Croat 2008; 47: 19-24

21. Tobelem G, Jacquillat C, Chastang C, Auclerc MF, Lechevallier T, Weil M, Daniel MT, Flandrin G, Harrousseau JL, Schaison G, Boiron M, Bernard J: Acute monoblastic leukemia: a clinical and biologic study of 74 cases. Blood 1980; 55: 71-76

22. Dusenbery KE, Howells WB, Arthur DC, Alonzo T, Lee JW, Kobrinsky N, Barnard DR, Wells RJ, Buckley JD, Lange BJ, Woods WG: Extramedullary leukemia in children with newly diagnosed acute myeloid leukemia: A report from the Children's Cancer Group. J Pediatr Hematol Oncol 2003; 25: 760-768

23. Jenkin RD, Al-Shabanah M, Al-Nasser A, El-Solh H, Aur R, Al Sudairy R, Mustafa MM, Al Fawaz I, Gray A, da Cunha M, Ayas M, Al Mahr M, Kofide A, Mahgoub AN, Rifai S, Belgaumi A, Al Jefri A, Al Musa A, Sabbah R: Extramedullary myeloid tumors in children: The limited value of local treatment. J Pediatr Hematol Oncol 2000; 22: 34-40 